\title{
Integrating the Information Systems: Proposal to develop a Library LMS
}

\author{
D.N.T. Gunawardhana \\ University of Moratuwa, Sri Lanka
}

\begin{abstract}
Library is not limited to offering resources for learning and teaching. Traditional library services are rapidly changing and library professionals are going beyond their limits of the duty list to provide maximum contribution to their users. They are coming out of the library and serve as resource persons, instructors, lecturers, research helpers, mentors, counselors and play many roles in the academic environment. They are giving their contribution to enhance learning and teaching by conducting lectures, seminars and workshops on research based sessions such as literature searching, plagiarism, referencing, thesis writing, abstract writing, research publishing, data analysis, research methodology etc. These works (content and knowledge) should be stored in an information system such as the University Learning Management System (LMS). With the COVID pandemic situation the need for such a system is very high due to the importance of online learning environment. That is why Library Learning Management System (Library LMS) is subjected to discussion. The duty list of library professionals is being redefined accordingly. Library professionals consist of the multidisciplinary subject streams. They contribute to teaching by conducting online lectures, creating online learning materials, providing new tools and techniques, conducting consultancy for research support using their subject knowledge. Then students will get many benefits such as download available learning materials, video lectures, make an appointment for online tutors, get "ask help" service and meet subject specialists when they have a "Library LMS". It may have two tasks when establish a "Library LMS". The first task is to develop a "Library LMS" as a sub system of the existing Library Management System. The second task is to integrate it with the University LMS.
\end{abstract}

Keywords: Learning Management System, Library Learning Management System, Library, Library LMS, LMS, University Libraries

\section{INTRODUCTION}

$\mathrm{U}$ niversities use the Learning Management Systems(LMS) as a tool to deliver lectures and learning materials, conduct online exams, conduct discussions, online meetings. "Educational services are being converted as electronic services from course registration to getting transcript certificates through Information Systems" (Gunawardhana, 2018, p. 16). "Libraries can and should explore ways of using LMSs to connect with students and faculty members to support teaching and learning" (Lockhart, 2021, p. 391). Libraries conduct programs on user awareness, literature searching, plagiarism and referencing, online resources, data analysis, research methodology as well. "In academic institutions the storage of libraries' resources is not enough and libraries must project them into users' learning environment" (Papic \& Stricevic, 2012, p. 239). "Librarians need to be proactive in integrating library resources into courseware, creating visibility and increasing the relevance and impact of the library to students and faculty" (Kampa, 2017, p. 16). Integrating library resources with the course modules help students for effective learning environment. "Each level of LMS integration depends on what the librarian can offer, what teaching faculty wants, and what will best benefit the students" (Landis, 2016). Libraries are not going to carry out programs subject wise as faculties of the university. But also they provide teaching and guidance to support research activities to enhancing students' knowledge. Therefore, managing the course content and delivery mechanism via a system such as University LMSis needed. Library management system is another system that is available in almost all university libraries to register students, acquisitions, circulations (issues and returns), search items, reserve items, renew items and to provide an effective library service. It is not functioning or focusing for teaching purposes. Faculties invite library professionals to conduct lectures to undergraduates and postgraduates. Some university libraries conduct their lectures as non-credit or credit modules accordingly. It has already been accepted and streamlined as an optional course module in their syllabus in some faculties. That means continuous development in this journey could be seen. Professional staff members have the opportunity to share their expert knowledge among students and give their fullest capacity by providing support for teaching. Therefore, the establishment of Library LMS is a timely and valuable achievement.

\section{OBJECTIVES}

According to Krier, (2021) librarians have to embrace their role as educators and connect all of the library's programs and functions to enhance the information literacy of students. Information literacy skills are very important for graduates in their degree programs and over their professional life. The objective of the study was to propose Library LMS for each university library in Sri Lanka and to discuss the possibility to integrate Library LMS and University LMS. Benefits for the students are getting opportunity to enhance their research knowledge, gaining extra-curricular experience, accessing information very quickly, having online discussion with subject librarians, accessing rich resources, sharing knowledge with information specialists, getting individual support for academic works, accessing content anytime and anywhere, getting an extra hand support. 


\section{IMPORTANCE OF LIBRARY LEARNING MANAGEMENT SYSTEM}

Learning Management System of the universities help students and lecturers to carry out their academic needs continuously in spite of COVID pandemic situation. "There is a wider acceptance of LMS in higher educational institutions, but services and resources of the library are missing from this eLearning environment" (Kampa, 2017, p. 16). Therefore, library services and resources have to be integrated with University LMS. "In recent academic libraries' theory and practice are very important trends is spreading their virtual presence through the integration into learning management systems (LMS)" (Papic \& Stricevic, 2012, p. 239). Library is a special place because the professional staff represent different subject areas. But faculties and departments recruit their academic staff according to their subject disciplines (e.g. all lecturers of Department of Sinhala come from relevant subject stream, all lecturers of Department of Mathematics come from relevant subject stream). However, Professional staff of university library come from different subject areas (Sinhala, Mathematics, Engineering, Statistics, Library Science, Information Technology, Languages etc.). Therefore, Library is a place where the professional staff consist of multi-disciplinary subject areas and talents. Library professionals who have teaching skills is a valuable asset for the university.

Having a Library LMS opens many doors for the students. "Students highly graded general effects of integration of libraries' e-services into LMS such as reduced time for searching learning materials, given unified access to sources for learning. Also, integration of libraries' e-services into LMS had positive effect on accomplishment of different students' learning tasks given by their teachers" (Papic \& Stricevic, 2012, p. 246). "It is felt that the integration of library resources and tools into an LMS is essential" (Kampa, 2017, p 16). Integrated library LMS makes benefit for all parties: students, lecturers, librarians, administration parties. It is a win-win situation for both students and library professionals as well. "Online modules reduce the librarian's limits on time and topics covered since the LMS allows students to go at their own pace and engage with the content that is relevant to their information need. So librarians may find more instructional freedom in LMS integration rather than getting cut short with "one shot" sessions" (Landis, 2016). "The general positive result of integration of libraries' e-services into learning management system could be seen in empowerment of relationships between students, teachers and librarians because e-services in LMS create new and enriched learning landscape" (Papic \& Stricevic, 2012, p. 246). Library LMS makes a positive impact on students' learning. Students can access the leaning materials, meet resource persons/lecturers via online (one to one session on booked appointments) and have discussions. Resource persons/lecturers can upload the lecture notes, videos and documents to Library LMS. Library LMS helps in promoting the library services as well.

\section{METHODOLOGY OF BACKGROUND STUDY}

Questionnaires were administered to undergraduate students of two selected universities in Sri Lanka. Krejcie and Morgan sampling technique used to decide the sample size. 626 students were included in the selected sample. They were informed to mention the order of importance of the components of the LMS based on students' needs and requirements. Suggestions and difficulties were asked when they use the university learning management system. Mixed analytical methods used to analyze the data. Thematic analysis and content analysis used to analyze qualitative data.

\section{DISCUSSION}

There may be several sub-components of an LMS. They are Registration process, Manage User Account, Library Services, Exam activities, Academic works (Lecture notes, Assignments, Notices), Administration works, Welfare, Financial, Online payments, Sports and extracurricular activities, Research and publications, Cafeteria (order online, pay online), Queries, Contact them, Other. Students gave their opinion as mentioned the table 1 .

Following is the priority order of LMS components according to the table 1 .

$1=$ Registration process, and Academic works (Lecture notes, Assignments, Notices),

$2=$ Exam activities,

$3=$ Library Services.

'Registration process and academic works' have taken the first place in the priority order, while 'online exam' has taken the second and the 'library services' is the third in the priority order. Next important items were 'user account management and administration works'. 'Financial works' through online payments has taken the next position. 'Research and publications, Cafeteria (order online, pay online) and Queries' were of less priority among system components.

'It is difficult to use several information systems, lack of availability of research papers, lack of extra readings, no space for research publications and resources, lack of online tutors' are some of the difficulties faced by students when they use University LMS. 'Adding external educational resources, including research and publication as a specific main menu in the site, adding recommended reading and questions, providing research support services, adding extra resources, research articles and past papers, providing 
Table 1: Prioritization of system components- order of Importance based on students needs and Requirements

\begin{tabular}{|c|c|c|c|c|c|c|c|c|c|c|c|c|}
\hline 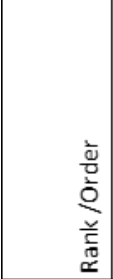 & 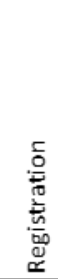 & 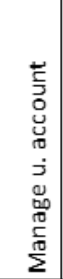 & 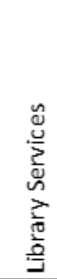 & 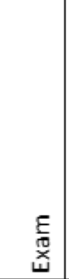 & 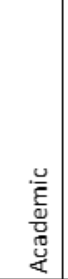 & 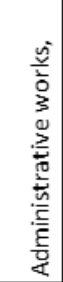 & 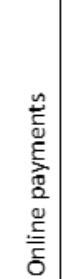 & 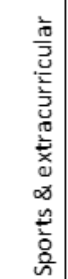 & 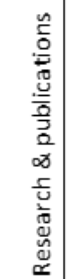 & 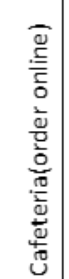 & 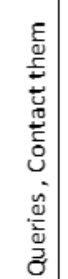 & $\begin{array}{l}\vdots \\
\vdots \\
\bar{\Phi} \\
\bar{c}\end{array}$ \\
\hline 1 & 222 & 57 & 47 & 91 & 260 & 32 & 23 & 31 & 47 & 38 & 86 & 0 \\
\hline 2 & 46 & 103 & 71 & 247 & 137 & 46 & 27 & 29 & 19 & 19 & 19 & 6 \\
\hline 3 & 63 & 72 & 217 & 111 & 70 & 48 & 58 & 35 & 29 & 31 & 17 & 3 \\
\hline 4 & 105 & 132 & 124 & 51 & 71 & 58 & 32 & 31 & 49 & 26 & 16 & 0 \\
\hline 5 & 132 & 136 & 70 & 100 & 49 & 83 & 58 & 24 & 68 & 17 & 33 & 0 \\
\hline 6 & 32 & 41 & 32 & 15 & 12 & 192 & 77 & 49 & 51 & 23 & 12 & 0 \\
\hline 7 & 16 & 23 & 29 & 6 & 11 & 42 & 161 & 81 & 90 & 22 & 32 & 0 \\
\hline 8 & 3 & 34 & 10 & 0 & 14 & 35 & 80 & 158 & 68 & 52 & 20 & 0 \\
\hline 9 & 2 & 6 & 11 & 0 & 1 & 21 & 57 & 143 & 143 & 65 & 43 & 0 \\
\hline 10 & 0 & 8 & 14 & 0 & 0 & 53 & 38 & 27 & 31 & 254 & 51 & 0 \\
\hline 11 & 0 & 14 & 1 & 2 & 0 & 13 & 9 & 18 & 25 & 79 & 289 & 4 \\
\hline 12 & 2 & 0 & 0 & 0 & 0 & 2 & 0 & 0 & 0 & 0 & 8 & 613 \\
\hline MODE & 1 & 5 & 3 & 2 & 1 & 6 & 7 & 8 & 9 & 10 & 11 & 12 \\
\hline
\end{tabular}

Alternative sites to access information, adding some more features like link to download research papers, including reference tools, include research articles and publications are some of the suggestions made by students. The reasonable solution to such issues seems to be Library LMS.

\section{THE WAY TO DEVELOP THE INTEGRATED LIBRARY LMS}

Libraries should provide new services and make opportunities to their users live at library in a virtual manner. When it can give a contribution to enhance learning and research culture, it become a prominent service. People all over the world live in a changing and challenging environment and "it is imperative for the library to remain an active part in the learning management system/virtual learning environment/online learning that is taking place" (Kampa, 2017, p. 18). "By integrating library resources into a course's LMS, librarians are getting a virtual foot in the door of the classroom" (Landis, 2016). All parties of the university carryout many projects to support students' betterments. "Findings from literature which stress the importance of academic librarians' cooperation with academic teachers because teachers have a key of subject contents within learning management systems and both should jointly work on developing of students' information literacy skills" (Papic \& Stricevic, 2012, p. 239). Usage of University LMS depends on their institutions. "Librarians should look at how the LMS is used at their institution" (Farkas, 2015). It is a need to have a discussion to identify internal human resources and students' needs to provide an optimum service via an integrated Library LMS.

Ajibade and Mutula (2020) have discussed the ways and possibility to conduct the virtual learning sessions in academic libraries. "The librarian should discuss with faculty members about the courses he/she teaches and collaborate with faculty to prepare reading lists, assignments and other learning resources on the subjects" (Kampa, 2017, p. 18). Library professionals able to collect recommended reading materials, research papers accordingly. Then those are uploaded continuously. Library can add more video lectures, online resources, new tools and techniques weekly. Students can log into the system using their user name and password. They can download available learning materials, video lectures, make an appointment for online tutors, get "ask help" service, meet subject specialists etc. "To facilitate students and teachers, librarians need to reassess their traditional roles, leverage new technologies and proactively develop collaboration with all stakeholders of an LMS" (Kampa, 2017, p. 18). It may have two tasks when establishing a library Learning Management System. The first task is to develop a Library LMS as a sub system of the existing Library Management System. The second task is to integrate the Library LMS with the University LMS. In the initial step, library professionals should analyses the faculty needs, gaps need to be filled. They can introduce their services accordingly and know the personal limitations.

\section{ACKNOWLEDGEMENT}

SRC grant of the University of Moratuwa, Katubedda Sri Lanka granted partial funds (grant number: SRC/ST/2018/24) for this research. Researcher is very much grateful to the Senate Research Committee of University of Moratuwa for granting the partial funds.

\section{REFERENCES}

[1] Ajibade, P., \& Mutula, S. M. (2020). Virtual learning: a disruptive service in academic libraries. Library Hi Tech News.

[2] Farkas, M. G. (2015). Libraries in the learning management system. Instructional technologies tips and trends. https://acrl. ala. org/IS/wp-content/uploads/2014/05/summer2015. pdf.

[3] Gunawardhana, D. N. T. (2018). Improving the Service Quality of Higher Education Institutions: Special reference to Information 
Systems. International Journal of Advanced Studies in Computers, Science and Engineering, 7(11), 13-17.

[4] Kampa, R.K. (2017), "Bridging the gap: integrating the library into Moodle learning management system a study", Library $\mathrm{Hi}$ Tech News, Vol. 34 No. 4, pp. 16-21. https://doi.org/10.1108/LHTN-11-2016-0055

[5] Krier, L. (2021). Library curriculum outside the classroom: Connecting library services to student learning. The Journal of Academic Librarianship, 47(2), 102303.
[6] Landis, C. (2016). Librarians in Learning Management Systems: Strategies and Suggestions. Got a minute? Instruction tune-up for time pressed librarians.

[7] Lockhart, J. (2021), "Embedding an information literacy course into a learning management system: a case study", Library Management, Vol. 42 No. 6/7, pp. 376394. https://doi.org/10.1108/LM-09-2020-0129

[8] Papic, A., \& Stricevic, I. (2012). Integration of academic libraries' e-services into learning management system: students' perception. In Management, Knowledge and Learning International Conference (pp. 239-246). 